\title{
Impairments in testicular function indices in male wistar rats: a possible mechanism for infertility induction by Xylopia aethiopica fruit extract
}

\author{
Ologhaguo Macstephen Adienbo*, Arthur Nwafor, Datonye Victor Dapper
}

\begin{abstract}
Department of Human Physiology, Faculty of Basic Medical Sciences, College of Health Sciences, University of Port Harcourt, Port Harcourt Nigeria
\end{abstract}

Received: 19 November 2014

Accepted: 20 December 2014

\section{*Correspondence:}

Dr. Ologhaguo Macstephen Adienbo,

E-mail: oologhaguo.adienbo@uniport.edu.ng, omadienbo@gmail.com

Copyright: (c) the author(s), publisher and licensee Medip Academy. This is an open-access article distributed under the terms of the Creative Commons Attribution Non-Commercial License, which permits unrestricted non-commercial use, distribution, and reproduction in any medium, provided the original work is properly cited.

\begin{abstract}
Background: The accumulating evidence about alterations in male fertility necessitates the need to screen more medicinal plants for their effect on male reproductive functions. This study is aimed at evaluating the effects of fruit extract of Xylopia aethiopica on testicular functions in males using wistar rats as models.

Methods: Forty eight adult male rats, randomly divided into four groups of 12 each, were used for the study. Group 1 (control), while groups 2, 3 and 4 (test groups). Daily oral doses of $0.5,2.0$ and $10.0 \mathrm{mg} / \mathrm{kg} \mathrm{b}$.w. of hydro-methanol extract were given to the test groups for 30 days followed by 30 days withdrawal. From each group, 6 animals were sacrificed on days 31 and 61 of the study and samples collected: Testes and epididymis were each weighed; blood was assayed for serum testosterone; testes processed for tissue biochemical studies.

Results: Results show significant $(\mathrm{P}<0.05)$ reductions in the weight of reproductive organs, serum testosterone; testicular glycogen, cholesterol, protein and malondialdehyde; while testicular superoxide dismutaase increased.

Conclusions: It was concluded that Xylopia aethiopica impairs testicular functions in rats and therefore fertility in males.
\end{abstract}

Keywords: Xylopia aethiopica, Testicular functions, Antifertility, Infertility

\section{INTRODUCTION}

Medicinal plants were considered in the past as the only form of health care readily available to the majority of human population, ${ }^{1}$ and it readily served as the most important weapon available to man to fight various human and animal diseases. This is especially true in many developing countries of the world where the use of plants by man for the treatment of various diseases has been in popular practice. ${ }^{2}$ Since evidence on the deterioration of parameters of male fertility is accumulating, ${ }^{3}$ the need to screen these medicinal plants for their effect on reproductive function in humans is therefore becoming more needful. This involves a proper assessment of their testicular effects since the testis is known to perform two important functions of spermatogenesis and steroidogenesis which affect fertility. Xylopia aethiopica is one of the very important tropical plants, with an outstanding usefulness both nutritionally, medicinally and otherwise. ${ }^{4}$

It has a wide variety of applications, and is readily available. ${ }^{5}$ The fruits are the most important parts of the plant, ${ }^{6}$ and are still an important item in local trade as spices, and flavoring for food and medicines. Few reports suggest that Xylopia aethiopica has antifertility and antigonadotropic effects, ${ }^{7,8}$ but none has examined its effects on testicular function indices, which is the aim of this study. 


\section{METHODS}

\section{Animal models}

Adult male wistar rats weighing between 160-225 g bred in the animal house of the department of human physiology, University of Port Harcourt, Nigeria were used for the study. The animals were housed separately in groups of 6 animals in clean wooden cages lined with wood chip beddings and maintained under standard conditions of temperature $\left(24-30^{\circ} \mathrm{C}\right)$, relative humidity (60-70\%), and natural light-dark cycle. The animals had free access to solid pellet diet (Livestock Feeds limited, Sapele Nigeria) and water ad. libitum throughout the study, except during the experiment. Experimental procedures in this study involving the animals and their care were conducted in conformity with the guiding principles for research involving animals. ${ }^{9}$

\section{Collection, identification and preparation of extract}

Dry fruits of Xylopia aethiopica purchased at Choba market in Port Harcourt were identified and authenticated at the department of forestry and wildlife management, faculty of agriculture, University of Port Harcourt. The identified fruits were washed, oven dried at $40^{\circ} \mathrm{C}$ to a constant weight. $1 \mathrm{~kg}$ of the dried fruit was ground to coarse powder form, $500 \mathrm{~g}$ of the powder refluxed in 2 liters of hydro-methanol solvent $(1: 4)$ at $60-70^{\circ} \mathrm{C}$ for 36 hours in a continuous extraction (soxhlet) apparatus. The extract was filtered and concentrated under reduced pressure at $60^{\circ} \mathrm{C}$ using a rotary evaporator, then preserved in a refrigerator at $-4^{\circ} \mathrm{C}$. When required the residue was suspended in olive oil to prepare fresh stock solutions of $0.1 \mathrm{mg} / \mathrm{ml}$ and $0.5 \mathrm{mg} / \mathrm{ml}$ respectively, from where the doses of extract used for this experiment were prepared: $0.5 \mathrm{mg} / \mathrm{kg}$ body weight, $2.0 \mathrm{mg} / \mathrm{kg}$ body weight, and $10 \mathrm{mg} / \mathrm{kg}$ body weight of the rats respectively.

\section{Study design}

Following 10 days of acclimatization, the male rats were randomly divided into four groups of 12 animals each: group1 was the control group, while groups 2-4 were test groups treated with $0.5 \mathrm{mg} / \mathrm{kg}$ body weight, $2 \mathrm{mg} / \mathrm{kg}$ body weight, and $10 \mathrm{mg} / \mathrm{kg}$ body weight doses respectively of hydro-methanolic extract of Xylopia aethiopica for 30 consecutive days, each in $1 \mathrm{ml}$ volume of the vehicle (olive oil) using animal-feeding intubation needles (Popper and Sons, New Hyde Park, NY). Similarly, animals in the control groups each received gastric infusion of $1 \mathrm{ml}$ olive oil in the same way as the experimental rats for same duration. After 30 days of extract administration, treatment was discontinued in all the test groups for 30 days to allow for a reversal of the effect of the extract on the animals. During the recovery period, food and water were supplied ad libitum, but extract and vehicle administration were discontinued. Six animals from each group were sacrificed on day 31 and the remaining 6 on 61 day of the study respectively. Blood was collected by cardiac puncture, spun at 2500 rpm for 10 minutes and the serum assayed for testosterone using the Enzyme Linked Immunoassay (EIA) technique. The testes and epididymis were each weighed. Testicular tissue was subsequently homogenized and the supernatant used for estimation of the following biochemical parameters by the methods earlier described: glycogen, ${ }^{10}$ cholesterol, ${ }^{11}$ protein, ${ }^{12}$ malondialdehyde ${ }^{13}$ and superoxide dismutase. ${ }^{14}$

\section{Statistical analysis}

Statistical tests were performed using the general linear models procedure in the Statistical Package for Social Sciences Software (SPSS; version 17.0, USA). Data were analyzed using one-way analysis of variance of means (ANOVA). Post hoc comparisons between the groups after ANOVA were made using post hoc Tukey HSD test. Differences at the probability level $\mathrm{P} \leq 0.05$ were considered statistically significant. The results, expressed as mean and standard error of mean were presented in table and figures.

\section{RESULTS}

\section{Effect of Xylopia aethiopica on weight of male reproductive organs}

The results of 30 days administration of the extract on the testicular weight shows a dose dependent decrease in the rats treated with $0.5 \mathrm{mg} / \mathrm{kg}$ b.w. $(\mathrm{P}>0.05), 2 \mathrm{mg} / \mathrm{kg}$ b.w. $(\mathrm{P}>0.05)$ and $10 \mathrm{mg} / \mathrm{kg}$ b.w. $(\mathrm{P}<0.05)$ test doses, when compared with the control group (Figure 2). Similarly, the epididymal weight showed a dose dependent decrease in the test animals treated with $0.5 \mathrm{mg} / \mathrm{kg}$ b.w. $(\mathrm{P}>0.05)$, $2 \mathrm{mg} / \mathrm{kg}$ b.w. $(\mathrm{P}<0.05)$ and $10 \mathrm{mg} / \mathrm{kg} \mathrm{b.w.}(\mathrm{P}<0.05)$ test doses, compared with the control group animals (Figure 2).

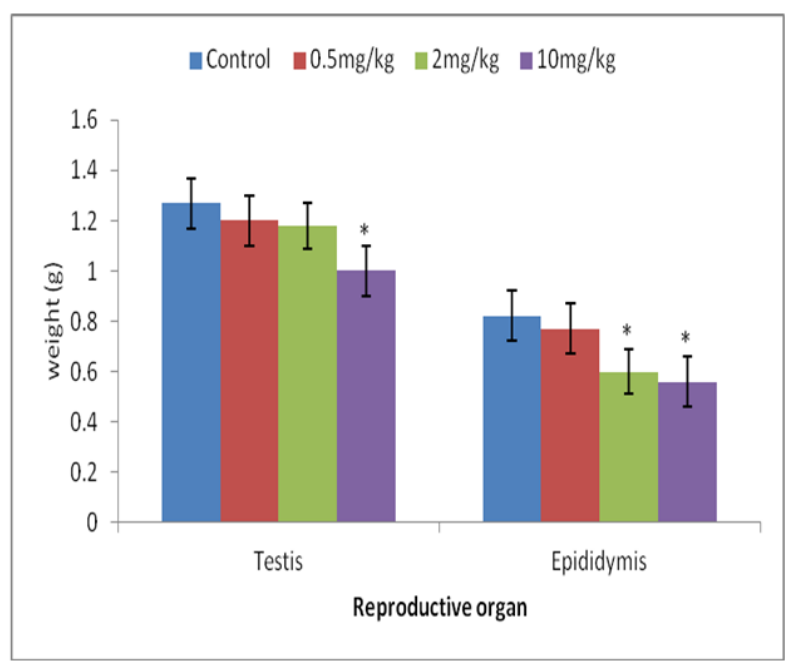

Figure 1: Bar charts showing effect of 30 days treatment of Xylopia aethiopica extract on the weight of reproductive organs in male rats. 


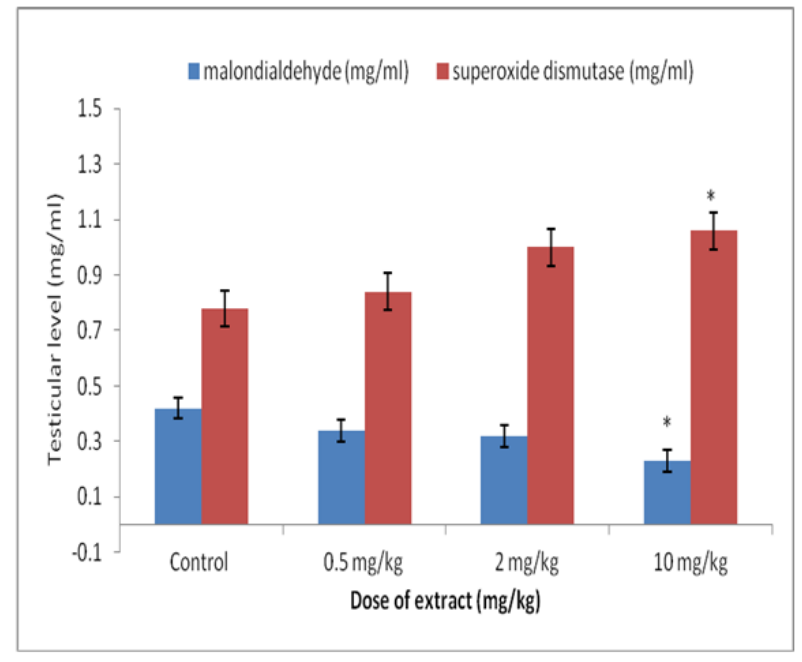

Figure 2: Histogram showing effects of 30 days treatment of Xylopia aethiopica extract on the testicular malondialdehyde and superoxide dismutase concentrations in male wistar rats. $(* \mathrm{P}<0.05)$.

\section{Effects of Xylopia aethiopica on testicular biochemical parameters and serum testosterone}

The result of 30 days treatment of animals in the test groups with Xylopia aethiopica extract (Table 1) shows a dose dependent significant $(\mathrm{P}<0.05)$ reduction in the testicular levels of all the biochemical parameters: glycogen, cholesterol and protein in all the animals in the test groups, when compared with those in the control group. Similarly, there was a significant $(\mathrm{P}<0.05)$ dose dependent decrease in the level of serum testosterone in rats in all the test groups, when compared with the control group animals.

However, after a 30 day withdrawal of extract administration (recovery period), there were nonsignificant $(P>0.05)$ increases in the concentrations of testicular glycogen, cholesterol and protein and serum testosterone in all the test groups, when compared with the control group animals (Table 2).

Table 1: Effect of Xylopia aethiopica on some testicular biochemical parameters and serum testosterone (M $\pm \mathrm{SE})$ levels in male rats after 30 days of treatment.

\begin{tabular}{|lllll|}
\hline Biochemical parameter & Dose of extract $(\mathbf{m g} / \mathbf{k g})$ & & \\
& Control & $\mathbf{0 . 5} \mathbf{~ m g} / \mathbf{k g}$ & $\mathbf{2} \mathbf{~ m g} / \mathbf{k g}$ & $\mathbf{1 0} \mathbf{~ m g} / \mathbf{k g}$ \\
\hline Testicular glycogen $(\mathrm{mg} / 100 \mathrm{mg}$ glucose $)$ & $3.25 \pm 0.02$ & $2.30 \pm 0.02^{*}$ & $1.17 \pm 0.00^{*}$ & $0.98 \pm 0.01^{* *}$ \\
\hline Testicular cholesterol $(\mathrm{mmol} / \mathrm{l})$ & $5.69 \pm 0.04$ & $3.95 \pm 0.04^{*}$ & $3.67 \pm 0.02^{* *}$ & $3.56 \pm 0.03^{* *}$ \\
\hline Testicular protein $(\mathrm{mg} / \mathrm{ml})$ & $17.26 \pm 0.7$ & $14.52 \pm 0.3^{*}$ & $13.43 \pm 0.4^{*}$ & $12.61 \pm 0.2^{*}$ \\
\hline Serum testosterone $(\mathrm{ng} / \mathrm{ml})$ & $1.40 \pm 0.06$ & $0.45 \pm 0.08^{* *}$ & $0.30 \pm 0.03^{* *}$ & $0.32 \pm 0.03^{* *}$ \\
\hline
\end{tabular}

$* \mathrm{P}<0.05, * * \mathrm{P}<0.01$

Table 2: Effect of Xylopia aethiopica on some testicular biochemical parameters and serum testosterone (M $\pm \mathrm{SE})$ levels in male rats after $\mathbf{3 0}$ days of treatment withdrawal (recovery).

\begin{tabular}{|lllll|}
\hline \multirow{2}{*}{ Biochemical parameter } & Dose of extract $(\mathbf{m g} / \mathbf{k g})$ & & \\
& Control & $\mathbf{0 . 5} \mathbf{~ m g} / \mathbf{k g}$ & $\mathbf{2} \mathbf{~ m g} / \mathbf{k g}$ & $\mathbf{1 0} \mathbf{~ m g} / \mathbf{k g}$ \\
\hline Testicular glycogen $(\mathrm{mg} / 100 \mathrm{mg}$ glucose $)$ & $2.98 \pm 0.02$ & $2.39 \pm 0.01$ & $2.37 \pm 0.03$ & $2.06 \pm 0.03$ \\
\hline Testicular cholesterol $(\mathrm{mmol} / \mathrm{l})$ & $5.54 \pm 0.05$ & $4.67 \pm 0.07$ & $5.35 \pm 0.05$ & $4.81 \pm 0.05$ \\
\hline Testicular protein $(\mathrm{mg} / \mathrm{ml})$ & $16.50 \pm 1.0$ & $15.98 \pm 1.5$ & $15.34 \pm 0.8$ & $15.06 \pm 1.2$ \\
\hline Serum testosterone $(\mathrm{ng} / \mathrm{ml})$ & $1.50 \pm 0.07$ & $1.60 \pm 0.05$ & $1.35 \pm 0.02$ & $1.62 \pm 0.08$ \\
\hline
\end{tabular}

The effects of Xylopia aethiopica on testicular malondialdehyde and superoxide dismutase activities, presented in Figure 2, shows a dose dependent but nonsignificant $(\mathrm{P}>0.05)$ decrease in the testicular concentrations of MDA in rats treated with $0.5 \mathrm{mg} / \mathrm{kg}$ b.w. and $2 \mathrm{mg} / \mathrm{kg} \mathrm{b.w}$. of the extract respectively, when compared with the control group animals. However, at the highest test dose of $10 \mathrm{mg} / \mathrm{kg}$ body weight, the reduction in testicular MDA level became statistically significant $(\mathrm{P}<0.05)$, when compared with the control group animals. The result for the testicular superoxide dismutase (SOD) activity shows a dose dependent increase in the test animals treated with $0.5 \mathrm{mg} / \mathrm{kg} \mathrm{b.w} \mathrm{(P}$ $>0.05), 2 \mathrm{mg} / \mathrm{kg} / \mathrm{kg} \mathrm{b.w}(\mathrm{P}>0.05)$ and $10 \mathrm{mg} / \mathrm{kg} / \mathrm{kg}$ b.w $(\mathrm{P}<0.05)$ of the extract, compared with the control group animals

\section{DISCUSSION}

The testes, epididymis and other reproductive organs are structurally and physiologically dependent upon testosterone and other androgens. Testosterone stimulates 
growth and secretary activities of these reproductive organs. ${ }^{15}$ Therefore, the decrease in the weights of the testes and epididymis observed in this study could be due to the decrease in the serum testosterone concentration, as studies have shown that the level of androgen is positively correlated with the weight of testis and epididymis. ${ }^{16}$ The decreased testosterone caused a decrease in the number and function of somatic and germinal cells of the testes, resulting to a reduction in the secretion of seminiferous tubular fluid as well as in spermatogenesis, both of which have been reported to contribute to the weight of testes. ${ }^{17}$

Testicular glycogen, cholesterol and protein are useful 'marker' indices of male testicular function. ${ }^{18,19}$ The result of this study shows a dose dependent significant decrease in the testicular concentrations of glycogen, cholesterol and protein. The reduction in testicular glycogen suggests that the extract caused a depletion of carbohydrate energy reserve for the seminiferous tubular cells since glycogen is an index of energy storage. ${ }^{20}$ This might be attributed to the reduction in the serum testosterone because glycogen content has been found to be directly proportional to the steroid hormones. ${ }^{21}$ The significant reduction in testicular glycogen will affect the plasma glucose and lactate levels necessary for glycolysis of seminiferous tubular cells. This will adversely affect spermatogenesis, and therefore fertility, by preventing the transformation of spermatocytes to spermatozoa. ${ }^{22}$

Mammalian cells require a constant supply of cholesterol which plays an important role as precursor molecule in the synthesis of most steroid hormones. ${ }^{17,23}$ Steroidogenesis is dependent on availability of cholesterol to the cytochrome P-450 cholesterol side chain cleavage (P450scc) enzyme complex within the mitochondria. $^{24}$ In this study, all the extract-treated animals showed significant decreases in the testicular cholesterol level, suggesting an alteration in its metabolism, induced by the extract.

Testicular proteins are androgen dependent, and are required for spermatogenesis and sperm maturation ${ }^{25}$. Studies have shown that protein synthesis in the gonads is associated with the plasma levels of testosterone and follicle stimulating hormone. ${ }^{26}$ The decrease in testicular protein observed in the extract-treated rats may therefore be due to a reduction in its synthesis resulting from the decrease in serum Testosterone. Such reduction in protein concentration will lead to impairments in testicular secretory and spermatogenic functions, which have been reported to cause male infertility. ${ }^{22}$

Testosterone is the main male gonadal hormone produced by the testicular interstitial cells of Leydig. ${ }^{27}$ In this study, a significant reduction in plasma testosterone, which is an indication of the anti-androgenic potential present in Xylopia aethiopica, was observed. This is similar to earlier reports ${ }^{28}$. Such decrease in testosterone concentration resulted from a decrease in serum luteinizing hormone concentration ${ }^{8}$ as well as from the decreased testicular cholesterol concentration observed in this study. The results from this study further suggest that the observed effects of the extract on testicular functions indices are reversible.

Tissue malondialdehyde (MDA) and superoxide dismutase (SOD) activities are useful markers of the oxidative state of an organ. MDA is the most abundant individual aldehyde resulting from lipid peroxidation breakdown in biological systems. The decrease in testicular MDA in the extract treated rats indicates a reduction in lipid peroxidation. The increase in the testicular level of SOD, on the other hand, suggests that Xylopia aethiopica potentiates free radical scavenging ability in the treated rats, and therefore possesses antioxidant activity. The antioxidant activity of Xylopia aethiopica can be attributed to its flavonoids phytoconstituents. $^{29}$

In conclusion, the present study reports that administration of fruit extract of Xylopia aethiopica causes reversible deleterious effects on testicular biochemical parameters and serum testosterone in albino wistar rats. These could therefore result to impairments in testicular functions, and therefore infertility, even in male humans.

\section{Funding: No funding sources Conflict of interest: None declared}

Ethical approval: The study was approved by the institutional animal ethics committee of the college of health sciences, University of Port Harcourt, Nigeria

\section{REFERENCES}

1. WHO. Reproductive health research at WHO: special programme of research. Development and research training in human reproduction. In: WHO, eds. Biennial Report. Geneva: World Health Organization; 2000: 1998-1999.

2. Sofowara A. Medicinal plants and traditional medicine in Africa. In: Sofowara A, eds. A Book. Ibadan, Nigeria: Spectrum Books Ltd; 1993: 289.

3. Mantovani A, Maranghi F. Risk assessment of chemicals potentially affecting male fertility. Contraception. 2005;72:308-13.

4. Babarinde Samuel A, Adebayo Moses A, Oduyemi Kolade. Integrating varietal resistance with Xylopia aethiopica (Dunal) A. Richard seed extract for the management of Sitophilus zeamais Motschulsky in stored maize. Afr J Biotechnol. 2008;7(8):1187-91.

5. Irvine FR. Xylopia aethiopica. In: Irvine FR, eds. Woody Plants of Ghana. 1st ed. Oxford: Oxford University Press; 1961: 67-76.

6. Burkhill I. Xylopia aethiopica. In: Burkhill I, eds. Useful Plants of Tropical West Africa. 2nd ed. London: Pergamon Press; 1985: 231-237.

7. Nwangwa EK. Antifertility effects of ethanolic extract of Xylopia aethiopica on male reproductive 
organ of wistar rats. Am J Med Med Sci. 2012;2(1):12-5.

8. Adienbo OM, Nwafor A, Iwuji S. Effect of aqueous fruit extract of Xylopia aethiopica on reproductive hormones in male guinea pigs. Glob J Pure Appl Sci. 2011;17(2):137-9.

9. American Physiological Society. Guiding principles for research involving animals and human beings. Am J Physiol. 2002;283:281-3.

10. Pongchaidecha A, Vasana P, Khansuwan U. Dietary fat and training enhance utilization of intramuscular triacylglycerol during exercise. Thai J Physiol Sci. 2006;19(2):16-29.

11. Plummer TD. Cholesterol estimation. In: Plummer TD, eds. An Introduction to Practical Biochemistry. 3rd ed. New Delhi: Tata McGraw-Hill Publishing Co. Ltd.; 1995: 189.

12. Kim Frederix, Ingeborg M. Kooter, René van Oerle, Diane Fens, Karly Hamulyak, Miriam E. GerlofsNijland, et al. A new method to determine tissue specific tissue factor thrombomodulin activities: endotoxin and particulate air pollution induced disbalance. Thromb J. 2008;6(14):1-11.

13. Buege JA, Aust SD. Microsomal lipid peroxidation. In: Fleischer S, Packer L, eds. Methods in Enzymology. 1st ed. New York: Academic Press; 1978: 302-330.

14. Rukmini MS, Benedict I, Vivian D. Superoxide dismutase and catalase activities and their correlation with malondialdehyde in schizophrenic patients. Int $\mathbf{J}$ Clin Biochem. 2004;19(2):114-8.

15. Singh J, O'Neill C, Handelsman DJ. Induction of spermatogenesis by androgens in gonadotropindeficient (hpg) mice. Endocrinology. 1995;136(12):5311-21.

16. Prins SG, Birch L, Greene GL. Androgen receptor localization in different cell types of the adult rat prostate. Endocrinology. 1991;129:3187-99.

17. Gupta RS, Chaudhary R, Yadav RK, Verma SK, Dobhal MP. Effects of saponins of Albizzia lebbeck (L.) benth bark on the reproductive system of male albino rats. J Ethnopharmacol. 2005;96:31-6.

18. Gonzales GF, Rubio J, Chung A, Gasco M, Villegas L. Effect of alcoholic extract of Lepidium meyenii (Maca) on testicular function in male rats. Asian $\mathrm{J}$ Androl. 2003;5:349-52.
19. Jana D, Maiti R, Ghosh D. Effect of Stephania hernandifolia leaf extract on testicular activity in rats. Asian J Androl. 2003;5:125-9.

20. Yakubu MT, Akanji MA, Oladiji AT. Sexual dysfunction and methods used in assessing medicinal plants with aphrodisiac potentials. Pharmocogn Rev. 2007;1:49-56.

21. Rommerts FFG, Cooke BA, Vander Molen HJ. The role of cyclic AMP in the regulation of steroid biosynthesis in testis tissue. J Steroid Biochem. 1974;5:279.

22. Adienbo OM, Nwafor A, Ogbomade RS. Contraceptive efficacy of hydro-methanolic fruit extract of Xylopia aethiopica in male albino rats. Int J Adv Biol Biom Res. 2013;1(7):718-27.

23. Das KK, Dasgupta S. Effect of nickel sulfate on testicular steroidogenesis in rats during protein restriction. Environ Health Persp. 2002;110:923-6.

24. Miller WL. Molecular biology of steroid hormone synthesis. Endocrine Rev. 1988;9:295-318.

25. Kasturi M, Sanivannan B, Ahmed NR, Shaikh PD, Pattan KM. Changes in epididymal structure and function of albino rat treated with Azardirachta indica leaves. Indian J Experiment Biol. 1995;33:725-9.

26. Gupta RS, Kachhawa JB, Chaudhary R. Antifertility effects of methanolic pod extract of Albizzia lebbeck. Asian J Androl. 2004;6:155-9.

27. Walton S, Cunliffe WJ, Kaczkes K, Early AS, McGarrigle HHG, Katz M. Clinical ultrasound and hormonal markers of androgenicity in acne vulgaris. Br J Dermatol. 1995;133(2):249-53.

28. Woode E, Alhassan A, Abaidoo CS. Effect of xylopic acid on sex hormones and spermatogenesis in male rats. Al Am J Med Sci. 2012;5(3):288-97.

29. Ezekwesili CN, Nwodo FC, Enehand FU, Ogbunugafor HA. Investigation of the chemical composition and biological activity of Xylopia aethiopica. Afr J Biotechnol. 2010;9(43):7352-6.

DOI: $10.5455 / 2320-1770 . i j r \operatorname{cog} 20150214$

Cite this article as: Adienbo OM, Nwafor A, Dapper DV. Impairments in testicular function indices in male wistar rats: a possible mechanism for infertility induction by Xylopia aethiopica fruit extract. Int J Reprod Contracept Obstet Gynecol 2015;4:71-5. 